\title{
Ethological and morpho-functional features of sexual cyclicity at cows in conditions of industrial production of milk
}

Sidashova S. ${ }^{1}$, Kovtun S. ${ }^{2}$, Shcherbak $0 .{ }^{3}$

M. Zubets Institute of Animal Breeding and Genetics of NAAS, Pogrebniak Str., 1, Chubinske, Boryspil region, Kyiv oblast, 08321, Ukraine; e-mail: 1 sidashova2020@ukr.net, 2 kovtun_si@i.ua, 3 ov19792006@gmail.ua

The purpose. To study ethologo-morphological features of manifestation of a stage of sexual excitement at cows of milk breeds in different economic-technological conditions. Methods. Ethological, biotechnological, zoo-technical, and statistical. Results. It is established that in the fixed interval of palpation up to 4 hours from the moment of detection of sexual excitement on the average 59,5\% (accordingly, with oscillations in different farms from 41,2 to $68,6 \%$ ) cows already had the beginning of ovulation of dominant follicle or ovulatory surface of ovary. It is shown that one-time artificial fertilization in a regime of the fixed interval from detection up to palpation has ensured on the average a pregnancy at the level of $60,2 \%$. Conclusions. For heightening productivity of artificial fertilization of cows it is necessary to consider ethological and morpho-functional features of sexual cyclicity at cows.

Key words: cows, sexual cycle, sexual excitement, ovaries, palpation, follicle, ovulation, breeding efficiency.

\section{https://doi.org/10.31073/agrovisnyk201806-08}

Breeding in cattle is a key element in the organization of efficient milk production. Fundamental changes in the technology of maintenance, operation of lactating livestock and intensification of breeding process led to a significant increase in dairy productivity of cows, holsteined breeds. At the same time, world statistics indicate a negative tendency to reduce the fertility of cows and heifers, which reduces the profitability of industrial dairy enterprises and the effectiveness of breeding work [1, 2, 3, 4].

The long-term study of the ethological and physiological features of the sexual function of female cattle has become the basis for the introduction of large-scale breeding in dairy cattle breeding, which would be impossible without artificial insemination of cows with cryopreserved donor sperm. The proper way of identifying cows for insemination is an important initial step that limits the reproduction effectiveness of the herd in the future.

It is well known that violations of the dynamics of the sexual cycle should be considered as a system of disorder relations of the sexual apparatus with other systems of the organism, as well as with the environment $[5,6,7,8]$.

Detailed field studies in the middle of the last century showed that the cow's ovulation occurs at the end of sexual hunting, most of the data is in 8-12 or 10-15 hours after the end of the hunt, which lasts an average of 13 hours, sometimes indicates a longer period of 3 up to 36 hours [8, 9, 10,11]. Generally accepted optimal time for insemination is sexual hunting, namely - its ending.

It is worth paying attention to the fact that the conditions for the cultivation, maintenance and exploitation of cows and heifers of dairy breeds have changed dramatically over the last decades in all developed livestock countries. The reproductive system of animal's acts as a biological structure, therefore, the sexual function of the cattle was subjected to transformation during the adaptation of the species to artificial environmental conditions. The vast majority of dairy enterprises of an industrial type do not even foresee in the technological processes the procedure of contact of bull-samplers with mother stock, considering the concentration of livestock and saturation by the mechanisms of production facilities.

Therefore, the question of correctly determining the optimal time for artificial insemination is currently relevant.

The analysis of literary data and the results of practical work [12] showed that in the conditions of industrial dairy enterprises, the formation of sexual cycles in cows and heifers has signs of inferiority as a result of a typical production situation - the absence of males - samplers, that is, alibility. As the sequence of 
other phenomena of the follicular phase, and especially the critical period - the process of ovulation of the dominant follicle, is formed, is not studied.

Differences in the determination of the intervals of the various phases of the stage of the sexual cycle, their beginning and ending, lead to errors in the organization of the regime of artificial insemination of cows in practical conditions of production, which negatively affect the final result of the efficiency of the dairy industry.

The purpose of the research is to study the ethological and morphological features of the manifestation of sexual excitation stage in cows of dairy breeds in various economic and technological conditions.

Materials and methods of research. The research was conducted during 2010-2016 in four dairy enterprises of industrial type, the main parameters of which are given in Table 1.

Observations of the sexual behavior of cows were carried out during animal walks [5]. The herd was examined twice before and after dinner milking, taking into account all animals with characteristic signs of sexual excitation $[7,10,11,13]$. During the four-hour interval (after fixation of animals in a machine or on a leash), their condition was confirmed by vaginal examination and rectal palpation of the uterus and ovaries. The morpho-physiological characteristics of the active ovary were used as a point of reference for optimum insemination, namely: the maturity of the dominant follicle and the actual or expected ovulation.

\section{Structure of the main economic and selection characteristics of dairy enterprises}

\begin{tabular}{|c|c|c|c|c|}
\hline \multirow[b]{2}{*}{ Indexes } & \multicolumn{4}{|c|}{ Farm } \\
\hline & $\begin{array}{l}\mathrm{LLC} \text { «AF» } \\
\text { «Zorya»» }\end{array}$ & $\begin{array}{c}\text { PC } \\
\text { «Poltavaplemser } \\
\text { vis» }\end{array}$ & $\begin{array}{c}\text { SE «EF im.Dekabry`stiv } \\
\text { PDSGS im. } \\
\text { M.I.Vavilova ISi APV } \\
\text { NAAN» }\end{array}$ & $\begin{array}{c}\text { ALLC «AF } \\
\text { «Petrodoly`ns`ke»» }\end{array}$ \\
\hline Year of the study & 2010 & 2011-2012 & 2015 & 2016 \\
\hline Breed & $\begin{array}{l}\text { red steppe, } \\
\text { crossbreed }\end{array}$ & $\begin{array}{l}\text { Ukrainian red and } \\
\text { motley dairy, } p / b\end{array}$ & Airshire, $\mathrm{p} / \mathrm{b}$ & $\begin{array}{l}\text { Ukrainian red milk, } \\
\text { crossbreed }\end{array}$ \\
\hline $\begin{array}{l}\text { Productivity, } \\
\text { kg of milk for lactation }\end{array}$ & 4800 & 8000 & 6000 & 5000 \\
\hline $\begin{array}{l}\text { Current Number of } \\
\text { Cows }\end{array}$ & 150 & 120 & 500 & 650 \\
\hline Eco-climatic area & Donecz`ka & Poltavs`ka & Poltavs`ka & Odes`ka \\
\hline Ways of keeping* & tied & tied & tied group & tied \\
\hline
\end{tabular}

* - all animals were provided with a daily walk in the conditions of the farms or the summer camp; milking - 3 times a day.

After rectal examination, at the same time interval, one-time artificial insemination of cows, which did not have gynecological contraindications and signs of an ovulatory, was performed by recto-cervical method using the cryopreserved bulls sperm, according to the breeding plan of the farm. For some high-yielding cows of Ukrainian red-and-montley dairy breeds at PC «Poltavaplemservis» used sperm divided by gender (XX-sperm). The efficiency of insemination was determined after 50-60 days by rectal examination.

Statistical parameters and their errors were counted by IBM SPSS Statistics - 2011 (Version 20) using the probability of the St'udent's criterion.

Results. As a result of observations, a similar picture of the processes of ripening of the dominant follicle during the stage of excitation of the sexual cycle of females of various herds and breeds of cattle was revealed (Table 2, Fig. 1). Already four hours after the first visual establishment of general sexual excitation in cows (reflexes of sexual intercourse, spliting on other cows, the so-called "reflex of real estate"), during the palpation examination of ovaries, an average of $32.9 \%$ of cows with ovulation appeared on the surface of the active ovary. In $26.6 \%$ of cycles - the condition of the dominant follicle, which was morphologically 
characterized as the beginning of ovulation (the follicle sheath lost its elasticity, small dent), was diagnosed. Visualization of palpation data is presented by models of ovaries in photos 1 and 2 .

A significant number of examined cows, which had already undergone ovulation after palpation, and, accordingly, the egg came out of the follicle into the space of the oviduct, had a prolongation of general sexual arousal, active sexual search and the so-called "reflex of real estate" as soon as they were released from the fixing machine. The results obtained by us have significant differences with the data given by other authors $[5,8,9,10,11]$.

Only $40.5 \%$ of the cycles (Table 2) in 383 subjects examined on the day 0 of cows, from one to four hours after the establishment of the first signs of sexual excitation, had a mature pre-ovulatory follicle, whose expected ovulation was postponed for another 6-12 hours (according to the performed palpation control).

2. Monitoring morphology of the active ovary of cows within 4 hours after the establishment of signs of general sexual arousal (estrus)

\begin{tabular}{|c|c|c|c|c|c|}
\hline \multirow{3}{*}{ Господарство } & \multirow{3}{*}{ \# (Cows) } & \multicolumn{4}{|c|}{ Installed during active palpation of the ovary: } \\
\hline & & \multicolumn{2}{|c|}{$\begin{array}{l}\text { Beginning of ovulation of the } \\
\text { dominant follicle * }\end{array}$} & \multicolumn{2}{|c|}{ Ovulation surface of the ovary ** } \\
\hline & & Cows & $\%$ & Cows & $\%$ \\
\hline LLC «AF» «Zorya»» & 78 & 17 & 21,8 & 16 & 20,5 \\
\hline PC «Poltavaplemservis» & 51 & 17 & 33,3 & 18 & 35,3 \\
\hline $\begin{array}{lll}\text { SE «EF } & \text { im.Dekabry`stiv } \\
\text { PDSGS im. } & \text { M.I.Vavilova ISi } \\
\text { APV NAAN» } & & \end{array}$ & 106 & 38 & 35,9 & 31 & 29,3 \\
\hline ALLC «AF «Petrodoly`ns`ke»» & 148 & 30 & 20,3 & 61 & 41,2 \\
\hline Total & 383 & 102 & 26,6 & 126 & 32,9 \\
\hline
\end{tabular}

Note: ${ }^{* * *} P>0,05$

It is established that the cows of various breeds in the conditions of industrial exploitation, nonsynchronous sexual cycles are formed, namely: ripening and ovulation of the dominant follicle passes much faster than established by researches in previous years. Experimentally revealed the interval between the first manifestation of sexual excitation of the cows and the ovulation of the dominant follicle, which was within 0-4 hours in $59.5 \%$ of cycles (Table 2). It is indicating about significant non-synchronicity in female behavior and maturation of the egg and, probably, about the preparation of the reproductive mucosa for the development of the embryo.

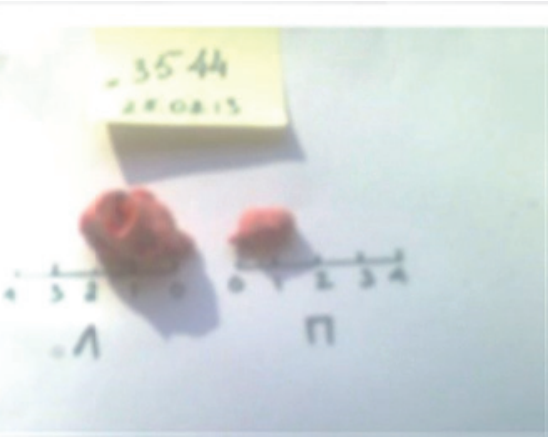

Photo 1. Model of cows ovaries on the day 0 of the cycle (there was a manifestation of signs of sexual excitation for 1 hour before palpation): on the surface of the left ovary - an ovulation fossa in place of the dominant follicle; the right ovary is not active, has signs of hypotrophy (PC «Poltavaplemservis»).

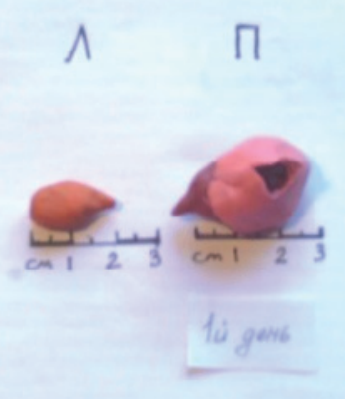

Photo 2. Model of cows ovaries on the day 0 of the cycle (there was a manifestation of signs of sexual excitation for 1 hour before palpation): on the surface of the right ovary - a dominant follicle with symptoms of the ovulation beginning; the left ovary does not function, has signs of hypotrophy (SE «EF im.Dekabry stiv PDSGS im. M.I.Vavilova ISi APV NAAN»). 
Visualization of data of rectal examination of cow's ovaries in a fixed interval from the beginning of detection of signs of an estrus. Volume models of ovaries based on the method of visualization of palpation (in vivo) data in real time - development of S.O. Sidashova.

Analysis of the morphological data of ovulatory state of cow's ovaries showed that in fact, females are only at the beginning of manifestation of sexual arousal in the form of search behavior and reaction to other females. The phenomenon of sexual hunting itself can not been traced as a result of the absence of male samplers in the herd. Such situation characterized changes in the relationship and mutual influence of ethological and physiological indicators.

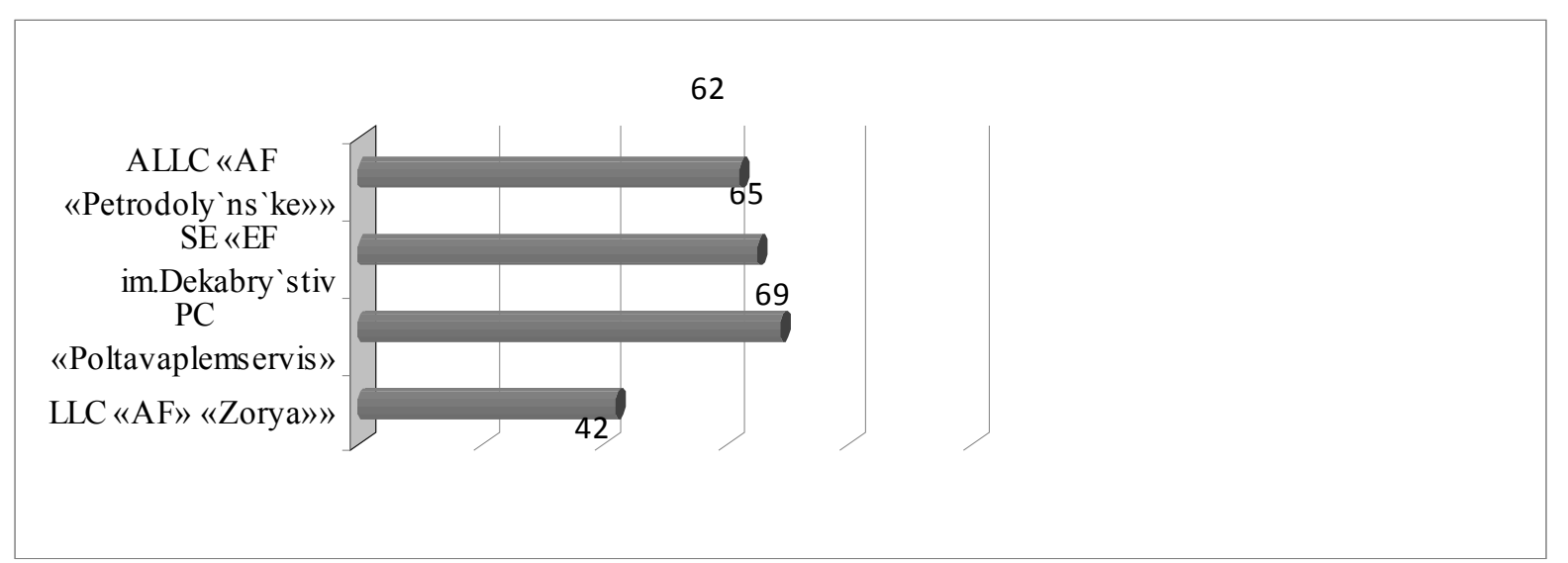

Figure 1. Detection of ovulation of dominant follicle in cows within an interval not more than 4 hours after establishing signs of general sexual arousal (estrus)

As a consequence of this artificially created state of constant retention of cows in same-sex groups without contact with males, there is a discrepancy between the terms of the manifestation of sexual reflexes and the course of hormonally determined processes in the follicular layer of the gonads. Due to the absence of biologically fixed stimulus, which ensured during the evolution of the species the presence of a male in a herd of cattle, the cows in industrial farms, the synchronicity of individual manifestations of the stage of excitation of the sexual cycle is violated, which characterizes the conditional inferiority of the cycle caused by the influence of paratypical (technogenic) factors.

Proceeding from the modern data of the suitability of cattle gametes to fertilization $[4,5,9]$, for instrumental insemination it is necessary to take the optimal interval of 4-6 hours after the first detection of signs of sexual excitation of cows. Longer terms, especially regarding the survival of sperm in the reproductive tract of cows, are not considered optimal for fertilization due to the accumulation of morphological damages of gametes, which provoke low vitality of embryos and early embryonic mortality [14].

The clarification needs to be made clear in the literature about the impossibility of insemination of animals in the absence of all consistent phenomena of a full-fledged sexual cycle [8]. To check the preliminary conclusions, we carried out artificial insemination of 168 cows (Table 3 ).

3. Fertility of cows after Al, conducted not earlier than four hours after the discovery of signs of estrus (general sexual arousal)

\begin{tabular}{|c|c|c|c|}
\hline \multirow{2}{*}{ Farm } & \multirow{2}{*}{$\begin{array}{l}\text { Total inseminated, } \\
\text { cows. }\end{array}$} & \multicolumn{2}{|c|}{ Got pregnant } \\
\hline & & Гол. & $\%$ \\
\hline LLC «AF» «Zorya»» & 78 & 54 & 69,2 \\
\hline PC «Poltavaplemservis» & $52^{*}$ & 22 & 42,3 \\
\hline $\begin{array}{l}\text { SE «EF im.Dekabry`stiv PDSGS im. } \\
\text { M.I.Vavilova ISi APV NAAN» }\end{array}$ & 38 & 25 & 65,8 \\
\hline 3 Farms Total $(\mathrm{M} \pm \mathrm{m})$ & 168 & 101 & 60,2 \\
\hline
\end{tabular}

Note: ${ }^{*}$ - incl. 21 cows in this group, insemination was sorted by sperm of imported bulls, from which 8 got pregnant (38.1\%). 
The actual level of cohabitation of experimental cows confirmed the accuracy of the selected single-dose insemination regime and indirectly demonstrated the probability of a trend toward conditional infertility of the sexual cycle, namely, the lack of synchronization of the manifestation of ovulation with regard to the beginning of apparent signs of female estrus in conditions of same-sex groups and the stress of animals with industrial milk dairy enterprises. It is necessary to consider during the organization of effective identification of cows for artificial insemination, that the sequence of the course of certain signs of sexual excitement in industrial conditions has changed.

The biometric processing of the results of the research did not show a reliable correlation between the data obtained at different farms, which indicating a significant effect of the morphological performance of the cows gonad and the level of fertilization of paratyphoid factors that were very diverse throughout the research period.

\section{Conclusions}

It was established that the manifestation of the ethological features of the stage of excitation of the sexual cycle and the physiological processes of maturation of the dominant follicle was not synchronous in $60 \%$ of the examined cows, it should be noted that no reliable influence of the breed or the eco-climatic zone of animal retention was not detected. The main factors of conditional infertility of sexual cycles of cows should be the influence of technogenic factors characteristic of industrial farms.

Palpatinously it was found that in $20-50 \%$ of cows, which only began to show sexual reflexes, ovulation of the dominant follicle has already occurred, indicating that the phenomena of sexual excitation are not synchronous with a significant fluctuation of indicators in the conditions of different farms.

The necessity of further study of changes in the formation of the sexual cycle of cows of dairy breeds is shown, for optimization of artificial insemination mode and increase of fertilization level in the conditions of industrial milk production technologies.

\section{References}

1. Sharapa H.S., Kuzebnyi S.V. (2015). Vidtvorna zdatnist i produktyvnist koriv novykh molochnykh pored. [The reproductive capacity and productivity of cows of new breeds]. Rozvedennia i henetyka tvaryn. V. 50. P. 225-229. [in Ukrainian].

2. Fedorovych V.V., Fedorovych Ye.I., Babik N.P., Oseredchuk R.S. (2016). Produktyvni yakosti tvaryn riznykh porid velykoi rohatoi khudoby. [Productive qualities of animals of different breeds of cattle]. Rozvedennia i henetyka tvaryn. V. 51. P. 160-169. [in Ukrainian].

3. Breeding strategies for sustainable mana-gement of animal genetic resources. Italy. (2010). Rome, № 3. $133 \mathrm{p}$.

4. Pereira R.V., Caixeta L.S., Giordano J.O. et al. (2013). Reproductive performance of dairy cows resynchronized after pregnancy diagnosis at 31 ( \pm 3 days) after artificial insemination (Al) compared with resynchronization at 31 ( \pm 3 days) after Al with pregnancy diagnosis at 38 ( \pm 3 days) after Al. J. Dairy Science. Dec. 96(12). P. 7630-7639.

5. Buhrov O.D. (2014). Vyiavlennia i vybirka koriv $i$ telyts u statevii okhoti. [Detection and selection of cows and heifers in sexual hunting]. Kharkiv: Instytut tvarynnytstva NAAN, 114 p. [in Ukrainian].

6. Davydenko V.M., Melnyk V.O., Zhuravel M.P. (2013). Akusherstvo, hinekolohiia i biotekhnolohiia vidtvorennia tvaryn. Terminolohichnyi slovnyk. [Obstetrics, gynecology and biotechnology of reproduction of animals. Terminology dictionary]. Mykolaiv: Mykolaivskyi natsionalnyi ahrarnyi universytet. 74 p. [in Ukrainian].

7. Kozlo N.E., Ozhin F.V., Parshutin G.V. et al. (1976). Iskusstvennoe osemenenie selskohozyajstvennyh zhivotnyh: albom. [Obstetrics, gynecology and biotechnology of reproduction of animals. Terminology dictionary]. Moskva: Kolos. 160 p. [in Russian].

8. Yablonskyi V.A. (Yablonskyi V.A. Ed). (2011). Veterynarne akusherstvo, hinekolohiia ta biotekhnolohiia vidtvorennia tvaryn z osnovamy androlohii: pidruchnyk. [Veterinary obstetrics, gynecology and biotechnology of reproduction of animals with the basics of andrology: a textbook]. Vinnytsia: Nova knyha. 608 c. [in Ukrainian].

9. Vattio M. (1996). Vosproizvodstvo i geneticheskaya selekciya. [Reproduction and genetic selection]. Mezhdunar. institut po issledovaniyu i razvitiyu molochnogo zhivotnovodstva. USA. Viskonsin,. 185 p. [in Russian].

10. Smirnov I.V. (1962). Iskusstvennoe osemenenie selskohozyajstvennyh zhivotnyh. [Artificial Insemination of Farm Animals]. Kiev: Gosselhozizdat. 291 p. [in Russian]. 
11. Studencov A.P. (1961). Akusherstvo, ginekologiya i iskusstvennoe osemenenie selskohozyajstvennyh zhivotnyh. [Obstetrics, gynecology and artificial insemination of farm animals]. Moskva: Selhozizdat. 542 p. [in Russian].

12. Sidashova S.O. (2014). Rezultatyvnist vidtvorennia diinoho stada i funktsionalna asymetriia yaiechnykiv koriv. [Resulting in the development of the dyadic herd and the functional asimetry of the yochnikiv koriv]. Visn. Dnipropetrovskoho derzhavnoho ahrar.-ekon. un-tu. № 2 (34). P. 175-181. [in Ukrainian].

13. Melnyk Yu.F. (Responsible ). (2001). Instruktsiia zi shtuchnoho osimeninnia koriv i telyts [Instruction for artificial insemination of cows and heifers]. Kyiv: Alfa-prynt. 40 p. [in Ukrainian].

14. Kastelic J.P., Northey D.L., Ginther O.J. (1991). Spontaneous embryonic death on days 20 to 40 in heifers. Theriogenology. V. 35. P. $351-363$. 